\section{Analisis Deskriptif Kepuasan Konsumen Atas Kualitas Pelayanan Delta SPA \& Health Club Palembang}

\author{
Yos Karimudin \\ Sekolah Tinggi Ilmu Ekonomi APRIN \\ Email: yos.karimudin@gmail.com
}

Service Quality and

Customer

Satisfaction

341

Submitted:

SEPTEMBER 2020

Accepted:

\begin{abstract}
ABSTRAK
Perkembangan dan peningkatan pelayanan Delta Spa \& Health Club Palembang dari tahun ke tahun semakin menjadi perhatian masyarakat. Hal ini dapat dilihat dari ketatnya persaingan kualitas pelayanan di berbagai tempat-tempat Spa yang berada di Palembang. Memberikan layanan yang baik terhadap semua orang adalah tugas yang mulia, terlebih bagi mereka yang bekerja di sektor pelayanan. Penelitian ini bertujuan untuk mengetahui analisis kualitas pelayanan terhadap kepuasan konsumen di Delta Spa \& Health Club Palembang. Metode yang digunakan dalam penelitian ini adalah metode survei, pengumpulan data diperoleh dengan menggunakan angket berupa pernyataan tertulis yang diberikan kepada responden untuk diisi dengan keadaan sebenarnya. Populasi dalam penelitian ini yaitu Konsumen Di Delta Spa \& Health Club Palembang. Teknik pengambilan sampel dalam penelitian ini menggunakan teknik insidental sampling sejumlah 65 orang responden..Analisis Citra digunakan untuk menganalisis data. Hasil penelitian ini menunjukkan bahwa kualitas pelayanan terhadap kepuasan konsumen di Delta Spa \& Health Club Palembang sebagian besar mempunyai sikap Puas sebesar 43,08 \%, sikap tidak puas sebesar 26,15\%, Sangat Tidak Puas 20,0 \% dan Sangat Puas 10,77 \%, dapat disimpulkan kualitas pelayanan terhadap kepuasan konsumen di Delta Spa $\&$ Health Club Palembang adalah Puas.
\end{abstract}

Kata Kunci: kualitas pelayanan, service product

\section{PENDAHULUAN}

Buruknya kualitas jasa (pelayanan) atau menejemen jasa yang diberikan perusahaan atau institusi publik kepada para konsumen, sudah sejak lama disadari mengakibatkan banyak kerugian bagi perusahaan. Jasa yang diberikan kepada konsumen juga sangat berhubungan langsung dengan keberlangsungan suatu perusahaan. Konsumen pada masa sekarang sudah mulai selektif untuk mencari tempat kebugaran yang bagus, dan baik secara pelayanannya.Itu berarti perusahaan bukannya melakukan marketing tetapi justru melakukan demarketing. Efek berikutnya akan terjadi pemberitaan yang negatif dalam jangka panjang. Dan sekali lagi itu adalah kerugian yang harus dialami oleh perusahaan.

Para pengelola tempat kebugaran bersaing untuk memberikan pelayanan yang terbaik bagi para konsumennya masing-masing. untuk itu para pengelola spa berusaha meningkatkan kualiats pelayanan mereka dengan menerapkan system manajemen tertentu. Kualitas pelayanan yang kurang baik maka akan memberikan efek tidak nyaman bagi konsumen yang datang, dana lama kelamaaan konsumen mulai beralih untuk menggunakan jasa spa yang di miliki pesaing atau di tempat lain. dengan kondisi persaingan yang ketat itu, hal utama yanag harus diprioritaskan oleh delta spa \& health

\section{JIMKES}

Jurnal Ilmiah Manajemen Kesatuan pp. $341-348$
IBI Kesatuan IBI Kesatuan
ISSN $2337-7860$ E-ISSN $2721-169 \mathrm{X}$ ol. 8 No. 3,2020 
Service Quality and Customer Satisfaction

\section{2}

club adalah kepuasan konsumen, agar dapat bertahan dan bersaing. Pengelola harus tahu hal apa saja yang dianggap penting oleh pengelola usaha untuk menghasilkan kinerja (performance) sebaik mungkin sehingga dapat memuaskan konsumen.

Pada saat ini perkembangan dunia bisnis salah satunya disebabkan oleh naiknya kesejahteraan masyarakat. Meningkatnya golongan menengah ke atas dari segi finansialnya, dan kepuasan konsumen. seiringan dengan hal tersebut, masyarakat pada saat ini cenderung tidak mempunyai banyak waktu untuk digunakan selain bekerja, sehingga membuat begitu banyak tempat penyedia jasa terlebih jasa Spa. Di Palembang juga banyak terdapat penyedia jasa tersebut dan diantaranya yaitu Delta Spa \& Health Club Palembang. Delta Spa \& Health Club adalah perusahaan yang bergerak di bidang jasa kebugaran. Dilihat dari perkembangannya perusahaan ini adalah perusahaan yang berkembang pesat pertumbuhannya, hal ini terbukti sejak awal pendiriannya pada tahun 1991 yang pada saat itu hanya mempunyai 1 cabang yang semuanya di dirikan di perhotelan di area Palembang sekarang telah menjadi lebih besar, terbukti pada saat ini Delta Spa \& Health Club Palembang memiliki 12 jabang di berbagai hotel. dengan adanya pembukaaan cabang baru ini bukan tidak mungkin Delta Spa \& Health Club Palembang akan menjadi salah satu perusahaan jasa Spa terbesar di Palembang.

Perkembangan dan peningkatan pelayanan Delta Spa \& Health Club Palembang dari tahun ke tahun semakin menjadi perhatian masyarakat. Hal ini dapat dilihat dari ketatnya persaingan kualitas pelayanan di berbagai tempat-tempat Spa yang berada di Palembang. Memberikan layanan yang baik terhadap semua orang adalah tugas yang mulia, terlebih bagi mereka yang bekerja di sektor pelayanan. Sebagai contoh konkrit orang bekerja sebagai terapis atau konsultan program di pusat-pusat kebugaran, memberikan layanan yang baik adalah sebagai tugas utamanya. Delta Spa \& Health Club merupakan salah satu perusahaan jasa pelayanan kebugaran sebagai salah satu cara supaya tubuh semakin sehat. Banyak treatment- treatment yang ditawarkan oleh Delta Spa \& Health Club Palembang.

Hal ini juga yang kemudian menjadikan sebuah indikasi bagi peneliti, apakah dengan banyaknya cabang yang ada, pihak perusahaan masih mengutamakan kualitas pelayanan yang baik, khususnya di bidang kualitas layanan yang di berikan kepada konsumen yang kebanyakan adalah tamu hotel yang berkunjung ke Palembang untuk berwisata dan juga yang lainnya. Juga bagaimana cara Delta Spa \& Health Club untuk mempublikasikan kepada masyarakat luas di sekitar hotel. dengan demikian apakah pelayanan yang diberikan kepada konsumen sesuai dan tepat sehingga bisa memberikan efek kepuasan bagi konsumen, sehingga konsumen yang kebanyakan adalah orang tamu dari luar kota masih banyak yang menggunakan jasa Delta Spa \& Health Club Palembang.

Berdasarkan batasan masalah di atas, maka dapat di rumuskan masalah sebagai berikut: "Bagaimana persepsi konsumen atas kualitas pelayanan Delta Spa \& Health Club Palembang?" Penelitian ini bertujuan untuk mengetahui persepsi konsumen atas kualitas pelayanan yang dapat menciptakan kepuasan konsumen di Delta Spa \& Health Club Palembang.

\section{METODE PENELITIAN}

Penelitian ini merupakan penelitian deskriptif, Metode yang digunakan dalam penelitian ini adalah metode survei, pengumpulan data diperoleh dengan menggunakan angket berupa pernyataan tertulis yang diberikan kepada responden untuk diisi dengan keadaan sebenarnya.

Populasi dalam penelitian ini yaitu Konsumen Di Delta Spa \& Health Club Palembang. Teknik pengambilan sampel dalam penelitian ini menggunakan teknik insidental sampling dimana semua konsumen yang datang di Delta Spa \& Health Club Palembang di semua outlet dalam kurun waktu satu minggu semuanya adalah sampel penelitian dan diperoleh sebanyak 65 orang. Metode yang digunakan dalam penelitian ini dengan menggunakan metode survey dan teknik pengumpulan data menggunakan angket yang diwujudkan dalam bentuk pernyataan. Data yang terkumpul dianalisis 
menggnakan Teknik deskriptif kuantitatif dengan prosentase adalah data kualitatif yang ada akan dikuantitatifkan, diangkakan sekedar untuk mempermudah dua atau lebih data variabel kemudian setelah dapat hasil akhir lalu dikualitatifkan kembali.
Service Quality and Customer Satisfaction

\section{HASIL DAN PEMBAHASAN}

\section{Deskripsi Data Hasil Penelitian}

Penelitian ini bermaksud untuk mengetahui tingkat kepuasan konsumen atas kualitas pelayanan Delta Spa \& Health Club Palembang. Secara terperinci deskripsi data diperoleh, rata-rata $($ mean $)=124,69$, median $=125$, modus sebesar $=135 ;$ standart devias $i$ $=12,29$.. Tabel distribusi data analisis kualitas pelayanan terhadap kepuasan konsumen di Delta Spa \& Health Club Palembang adalah sebagai berikut:

Tabel 1. Distribusi Frekuensi Analisis Kualitas Pelayanan Terhadap Kepuasan Konsumen di Delta Spa \& Health Club Palembang

\begin{tabular}{|c|c|c|c|c|}
\hline No & Interval & Kategori & Frekuensi & \% \\
\hline 1 & $\geq 136,98$ & Sangat Puas & 7 & 10,77 \\
\hline 2 & $124,69>X \geq 136,97$ & Puas & 28 & 43,08 \\
\hline 3 & $112,4>X \geq 124,68$ & Tidak Puas & 17 & 26,15 \\
\hline 4 & $<112,4$ & Sangat Tidak Puas & 13 & 20 \\
\hline \multicolumn{2}{|c|}{ Jumlah } & $\mathbf{6 5}$ & $\mathbf{1 0 0}$ \\
\hline
\end{tabular}

Hasil tabel tersebut apabila ditampilkan dalam bentuk diagram telihat sebagai berikut:

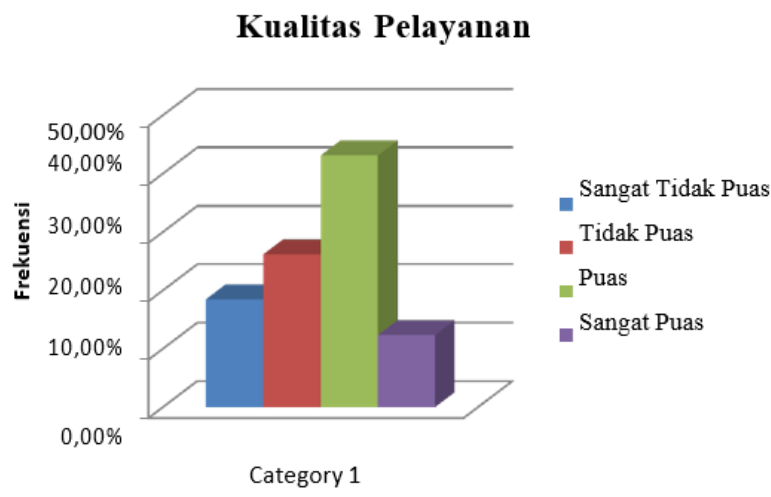

\section{Gambar 1. Diagram Analisis Kualitas Pelayanan Terhadap Kepuasan Konsumen di Delta Spa \& Health Club Palembang}

Berdasarkan tabel dan gambar penelitian tersebut dari 65 responden diketahui analisis kualitas pelayanan terhadap kepuasan konsumen di Delta Spa \& Health Club Palembang sebagian besar mempunyai sikap Puas sebesar 43,08\%, sikap tidak puas sebesar $26,15 \%$, Sangat Tidak Puas $20 \%$ dan Sangat Puas 10,77 \%. Berdasarkan hasil penelitian tersebut diartikan kualitas pelayanan terhadap kepuasan konsumen di Delta Spa \& Health Club Palembang adalah Puas. Hasil penelitian didasarkan pada faktor yang mempengaruhi analisis kualitas pelayanan terhadap kepuasan konsumen di Delta Spa \& Health Club Palembang dapat diuraikan sebagai berikut:

\section{Faktor Bukti langsung}

Hasil penghitungan data faktor bukti langsung diperoleh rata-rata $($ mean $)=38,41$, median $=39$, modus sebesar $=40$; standart deviasi $=4,86$. Tabel distribusi data faktor bukti langsung sebagaimana Tabel 2.

Berdasarkan tabel 2 penelitian tersebut dari 65 responden diketahui analisis kualitas pelayanan terhadap kepuasan konsumen di Delta Spa \& Health Club Palembang berdasarkan faktor bukti langsung sebagian besar mempunyai sikap Puas sebesar $40 \%$, sikap tidak puas sebesar 30,77\%, sangat tidak puas sebesar 15,38 \% dan sangat puas sebesar $13,85 \%$. 
Service Quality and Tabel 2. Distribusi Frekuensi Kepuasan Konsumen atas Faktor Bukti Langsung Customer Satisfaction

\begin{tabular}{|c|c|c|c|c|}
\hline No & Interval & Kategori & Frekuensi & $\%$ \\
\hline 1 & $\geq 43,27$ & Sangat Puas & 9 & 13,85 \\
\hline 2 & $38,41>X \geq 43,26$ & Puas & 26 & 40 \\
\hline 3 & $33,55>X \geq 38,40$ & Tidak Puas & 20 & 30,77 \\
\hline 4 & $<33,55$ & Sangat Tidak Puas & 10 & 15,38 \\
\hline \multicolumn{3}{|c|}{ Jumlah } & 65 & 100 \\
\hline
\end{tabular}

\section{Faktor Keandalan}

Hasil penghitungan data faktor keandalan diperoleh rata-rata $($ mean $)=24,23$, median $=24$, modus sebesar $=22$; standart devias $i=3,53$. Tabel distribusi data faktor keandalan adalah sebagai berikut:

Tabel 3. Distribusi Frekuensi Kepuasan Konsumen atas Faktor Keandalan

\begin{tabular}{|c|c|c|c|c|}
\hline No & Interval & Kategori & Frekuensi & $\%$ \\
\hline 1 & $\geq 27,76$ & Sangat Puas & 16 & 24,62 \\
\hline 2 & $24,23>X \geq 27,75$ & Puas & 11 & 16,92 \\
\hline 3 & $20,7>X \geq 24,22$ & Tidak Puas & 30 & 46,15 \\
\hline 4 & $<20,7$ & Sangat Tidak Puas & 8 & 12,31 \\
\hline \multicolumn{3}{|c|}{ Jumlah } & 65 & 100 \\
\hline
\end{tabular}

Berdasarkan tabel penelitian tersebut dari 65 responden diketahui analisis kualitas pelayanan terhadap kepuasan konsumen di Delta Spa \& Health Club Palembang berdasarkan faktor keandalan sebagian besar mempunyai sikap tidak puas sebesar $46,15 \%$, sikap sangat puas sebesar $24,62 \%$, Puas sebesar $16,92 \%$ dan Sangat tidak Puas sebesar $12,31 \%$.

\section{Faktor Daya tanggap}

Hasil penghitungan data faktor daya tanggap rata-rata (mean) $=17,49$, median $=18$, modus sebesar $=15$; standart deviasi $=2,62$. Tabel distribusi data faktor daya tanggap adalah sebagai berikut:

Tabel 4. Distribusi Frekuensi Kepuasan Konsumen atas Faktor Daya tanggap

\begin{tabular}{|c|c|c|c|c|}
\hline No & Interval & Kategori & Frekuensi & $\%$ \\
\hline 1 & $\geq 20,11$ & Sangat Puas & 11 & 16,92 \\
\hline 2 & $17,49>X \geq 20,10$ & Puas & 22 & 33,85 \\
\hline 3 & $14,87>X \geq 17,48$ & Tidak Puas & 28 & 43,08 \\
\hline 4 & $<14,87$ & Sangat Tidak Puas & 4 & 6,15 \\
\hline \multicolumn{3}{|c|}{ Jumlah } & 65 & 100 \\
\hline
\end{tabular}

Berdasarkan tabel penelitian tersebut dari 65 responden diketahui analisis kualitas pelayanan terhadap kepuasan konsumen di Delta Spa \& Health Club Palembang berdasarkan faktor daya tanggap sebagian besar mempunyai sikap tidak Puas sebesar $43,08 \%$, sikap puas sebesar 33,85\%, Sangat Puas sebesar $16,92 \%$ dan Sangat tidak puas Puas sebesar 6,15\%.

\section{Faktor Jaminan}

Hasil penghitungan data faktor jaminan rata-rata $($ mean $)=17,81$, median $=18$, modus sebesar $=18$; standart deviasi $=2,39$. Berdasarkan tabel 5 penelitian tersebut dari 65 responden diketahui analisis kualitas pelayanan terhadap kepuasan konsumen di Delta Spa \& Health Club Palembang berdasarkan faktor jaminan sebagian besar mempunyai sikap Puas sebesar 53,85 \%, sikap tidak puas sebesar 26,15 \%, Sangat Puas sebesar 10,77 $\%$ dan Sangat tidak Puas sebesar 9,23 \%.. 
Tabel 5. Distribusi Frekuensi Kepuasan Konsumen atas Faktor Jaminan

\begin{tabular}{|c|c|c|c|c|}
\hline No & Interval & Kategori & Frekuensi & \% \\
\hline 1 & $\geq 20,2$ & Sangat Puas & 7 & 10,77 \\
\hline 2 & $17,81>X \geq 20,19$ & Puas & 35 & 53,85 \\
\hline 3 & $15,42>X \geq 17,80$ & Tidak Puas & 17 & 26,15 \\
\hline 4 & $<15,42$ & Sangat Tidak Puas & 6 & 9,23 \\
\hline \multicolumn{2}{|r|}{ Jumlah } & $\mathbf{6 5}$ & $\mathbf{1 0 0}$ \\
\hline
\end{tabular}

\section{Faktor Empati}

Hasil penghitungan data Faktor empati rata-rata $($ mean $)=26,73$, median $=27$, modus sebesar $=27$; standart deviasi $=3,07$. Tabel distribusi data Faktor empati, sebagai berikut:

Tabel 6. Distribusi Frekuensi Kepuasan Konsumen atas Faktor Empati

\begin{tabular}{|c|c|c|c|c|}
\hline No & Interval & Kategori & Frekuensi & $\%$ \\
\hline 1 & $\geq 29,8$ & Sangat Puas & 13 & 20 \\
\hline 2 & $26,73>X \geq 29,8$ & Puas & 25 & 38,46 \\
\hline 3 & $23,66>X \geq 26,73$ & Tidak Puas & 21 & 32,31 \\
\hline 4 & $<23,66$ & Sangat Tidak Puas & 6 & 9,23 \\
\hline \multicolumn{3}{|c|}{ Jumlah } & 65 & 100 \\
\hline
\end{tabular}

Berdasarkan tabel penelitian tersebut dari 65 responden diketahui analisis kualitas pelayanan terhadap kepuasan konsumen di Delta Spa \& Health Club Palembang berdasarkan faktor empati sebagian besar mempunyai sikap Puas sebesar 38,46\%, sikap tidak puas sebesar 32,31\%, Sangat Puas sebesar $20 \%$ dan Sangat tidak Puas sebesar $9,23 \%$.

\section{Pembahasan}

Kepuasan pelanggan atau konsumen merupakan fungsi dari perbedaan antara kinerja yang dirasakan dengan harapan. Apabila kinerja dibawah harapan, maka konsumen akan kecewa. Tetapi apabila kinerja sesuai dengan harapan, pelanggan akan puas. Pelangggan yang puas akan setia lebih lama, kurang sensitif terhadap harga dan memberi komentar yang baik terhadap kinerja perusahaan.

Kepuasan konsumen/pelanggan merupakan tingkat kepuasan seseorang setelah membandingkan (kinerja atau hasil) yang dirasakan dibandingkan dengan harapannya. jadi tingkat kepuasan adalah fungsi dari perbedaan antara kinerja yang dirasakan dengan harapan. konsumen bisa memahami salah satu dari tiga tingkat kepuasan umum yaitu kalau kinerja di bawah harapan, konsumen akan merasa kecewa, tetapi kinerja sesuai dengan harapan pelanggan akan merasa puas dan bila kinerja bisa melebihi harapan maka pelanggan akan merasa sangat puas senang atau sangat gembira. Untuk menciptakan kepuasan pelanggan, perusahaan menciptakan dan mengelola suatu sistem untuk memperoleh pelanggan yang lebih banyak dari kemampuan untuk mempertahankan pelanggannya.

Delta Spa \& Health Club Palembang merupakan salah satu badan usaha yang sangat memperhatikan kepuasan konsumen, karena Delta Spa \& Health Club Palembang merupakan salah satu badan usaha yang menjual jasa bagi konsumen. Salah satu faktor untuk tetap menjaga kepuasan konsumen dan pelanggan salah satunya adalah dengan meningkatkan atau menjaga kualitas layanan yang diberikan.

Berdasarkan hasil penelitian di ketahui terdapat dua variabel yang persentase tidak puasnya lebih besar dari persentase puas ataupun sangat puas. Dua variabel tersebut yaitu pada variabel keandalan dan daya tanggap. Pada variabel tersebut responden yang menyatakan tidak puas lebih besar di bandingkan dengan yang menyatakan puas atau sangat puas. Pada variabel keandalan respoden yang menyatakan puas sebesar $16,92 \%$ atau 11 responden yang menyatakan puas, sedangkan yang menyatakan tidak puas sebesar $46,15 \%$ atau 30 responden yang menyatakan tidak puas. Pada variabel daya tanggap juga menarik, dimana $43,08 \%$ atau sebanyak 28 responden 
Service Quality and Customer Satisfaction

menyatakan tidak puas, sedangakan $33,85 \%$ atau 22 responden menyatakan puas. Responden yang menyatakan tidak puas berdasarkan hasil penelitian tersebut diartikan pada variabel tersebut perlu adanya evaluasi dan tindak lanjut dari manajemen Delta Spa \& Health Club Palembang. Hasil yang signifikan juga terjadi pada variabel jaminan dimana $53,85 \%$ atau 35 responden menyatakan puas dan $26,15 \%$ atau 17 responden manyatakan tidak puas. Secara keseluruhan berdasarkan hasil penelitian diketahui kualitas pelayanan terhadap kepuasan konsumen di Delta Spa \& Health Club sebagian besar mempunyai sikap Puas sebesar 43,07 \%, sikap tidak puas sebesar 26,15\%, Sangat Tidak Puas 20,0 \% dan Sangat Puas 10,77 \%. Hasil secara keseluruhan dari penelitian ini dengan hasil tersebut dapat diartikan pelanggan memberikan persepsi atau tanggapan puas terhadap kualitas pelayanan di Delta Spa \& Health Club Palembang.

Kualitas pelayanan adalah upaya pemenuhan kebutuhan dan keinginan pelanggan, serta ketetapan penyampaiannya untuk mengimbangi harapan pelanggan, kualitas jasa pelayanan merupakan kondisi dari kinerja yang dimiliki oleh suatu perusahaan dalam memberikan pelayanan kepada pelanggan dengan tujuan untuk memberikan kepuasan kepada pelanggan/konsumen. Berdasarkkan hasil tersebut diartikan bahwa kualitas pelayanan mempunyai pengaruh terhadap kepuasan konsumen di Delta Spa \& Health Club Palembang, jika kualitas layanan yang diberikan sudah cukup baik, bisa berpengaruh terhadap kepuasan pelanggan. Dalam penelitian ini kualitas layanan yang diteliti didasarkan pada beberapa faktor yaitu faktor bukti langsung, keandalan, daya tanggap, jaminan dan empati.

\section{Faktor Bukti Langsung}

Berdasarkan hasil penelitian penelitian analisis kualitas pelayanan terhadap kepuasan konsumen di Delta Spa \& Health Club berdasarkan faktor bukti langsung diketahui mempunyai sikap Puas sebesar $40 \%$, sikap tidak puas sebesar 30,77\%, Sangat Tidak Puas sebesar 15,38 \% dan Sangat Puas sebesar 13,85 \%. Bukti fisik langsung dalam kualitas layanan merupakan bentuk aktualisasi nyata secara fisik dapat terlihat atau digunakan oleh pegawai sesuai dengan penggunaan dan pemanfaatannya yang dapat dirasakan membantu pelayanan yang diterima oleh orang yang menginginkan pelayanan, sehingga puas atas pelayanan yang dirasakan, yang sekaligus menunjukan prestasi kerja atas pemberian pelayanan yang diberikan

Hasil berdasarkan penelitian pada faktor bukti langsung diartikan bahwa Di Delta Spa \& Health Club Palembang sudah mempunyai fasilitas dan kelenggkapan sarana dan prasarana yang memadai dan sesuai dengan kebutuhan konsumen yang dibutuhkan. Dengan adanya fasilitas dan sarana prasarana yang memadai maka konsumen menjadi terpuaskan karena yang diharapkan dalam pelayanan dapat tercapai dengan baik.

\section{Faktor Keandalan}

Berdasarkan hasil penelitian analisis kualitas pelayanan terhadap kepuasan konsumen di Delta Spa \& Health Club Palembang berdasarkan factor keandalan diperoleh mempunyai sikap tidak puas sebesar $46,15 \%$, sikap sangat puas sebesar 24,62 $\%$, puas sebesar $16,92 \%$ dan sangat tidak puas sebesar $12,31 \%$. Keandalan dapat diartikan memberikan pelayanan, setiap pegawai diharapkan memiliki kemampuan dalam pengetahuan, keahlian, kemandirian, penguasaan, dan profesionalisme kerja yang tinggi, sehingga aktifitas kerja yang dikerjakan menghasilkan bentuk pelayanan yang memuaskan, tanpa ada keluhan dan kesan yang berlebihan atas pelayanan yang diterima oleh masyarakat.

Hasil berdasarkan faktor keandalan di atas diartikan Di Delta Spa \& Health Club Palembang mempunyai menejemen waktu, jasa yang cukup baik dalam hal menejemen waktu yang baik seperti; buka tepat waktu, lokasi yang strategis dan biaya yang diberikan juga sesuai dengan dengan layanan yang diberikan. Akan tetapi beberapa hal yang masih memebuat konsumen mempunyai persepsi kurang puas dikarenakan beberapa pelayanan atau pegawai belum mempunyai pengetahuan yang baik dalam memberikan pelayanan. Hal tersebut dikarenakan beberapa pegawai merupakan pegawai baru dan beberapa pegawai masih mempunyai pendidikan menengah atau lulusan Sekolah Menengah Atas. 
Berdasarkan hasil penelitian diketahui analisis kualitas pelayanan terhadap kepuasan diperoleh sikap tidak puas sebesar 43,08 \%, sikap puas sebesar 33,85\%, Sangat Puas sebesar 16,92 \% dan Sangat tidak puas sebesar 6,15\%. Daya tangggap diartikan merupakan penjelasan yang bijak sana, mendetail, membina, mengarahkan dan membujuk agar menyikapi segala bentuk-bentuk prosedur dan mekanisme kerja yang berlaku dalam suatu organisasi, sehingga bentuk palayanan mendapat respon positif.

Berdasarkan faktor daya tanggap diartikan di Delta Spa \& Health Club Palembang bahwa karyawan bekerja dengan tanggap, melayani, dengan ramah, sopan dan tidak megecewakan. Para karyawan dipilih dan diajarkan untuk memberikan pelayanana yang baik, jika karyawan bersikap sopan, ramah maka para konsumen pasti akan merasa senang dan puas dalam menerima palayanan dari Delta Spa \& Health Club. Meskipun demikian kadang beberapa karyawan kurang maksimal dalam memberikan pelayanan kepada konsumen, hal tersebut dibuktikan dengan beberapa konsumen merasa kurang puas dengan sikap yang diberikan oleh pegawai

\section{Faktor Jaminan}

Berdasarkan hasil penelitian analisis kualitas pelayanan terhadap kepuasan konsumen di Delta Spa \& Health Club Palembang berdasarkan faktor jaminan diperoleh mempunyai sikap Puas sebesar 53,85 \%, sikap tidak puas sebesar 26,15\%, Sangat Puas sebesar 10,77 \% dan Sangat tidak Puas sebesar 9,23\%. Jaminan merupakan Bentuk kepastian dari suatu layanan sangat ditentukan oleh jaminan dari pegawai yang memberikan pelayanan, sehingga orang yang menerima pelayanan semakin puas dan yakin bahwa segala bentuk urusan pelayanan yang diberikan akan tuntas dan selesai sesuai dengan kecepatan, ketepatan, kemudahan, kelancaran dan kualitas layanan yang diberikan.

Hasil berdasarkan faktor jaminan diartikan Di Delta Spa \& Health Club Palembang menberikan keselamatan dan keamanan bagi pelanggan, baik dari tempat parkir, fasilitas yang aman dan nyaman bagi pelanggan, tempat yang bersih dan strategis. Hal tersebut menjadi nilai yang baik bagi sebuah tempat Spa, dikarenakan pelanggan akan merasa nyaman dan puas jika tempat yang dituju mudah, aman dan nyaman.

\section{Faktor Empati}

Berdasarkan hasil penelitian analisis kualitas pelayanan terhadap kepuasan konsumen di Delta Spa \& Health Club Palembang berdasarkan faktor empati diperoleh sikap puas sebesar 38,46\%, sikap tidak puas sebesar 32,31\%, sangat puas sebesar $20 \%$ dan Sangat tidak Puas sebesar 9,23\%. Empati dalam penelitian ini diartikan aktivitas pelayanan yang memerlukan pemahaman dan pengertian dalam kebersamaan asumsi atau kepentingan terhadap suatu hal yang berkaitan dengan pelayanan. Pelayanan akan berjalan dengan lancar dan berkualitas apabila setiap pihak yang berkepentingan dengan pelayanan memiliki adanya rasa empati (empathy) dalam menyelesaikan atau mengurus atau memiliki komitmen yang sama terhadap pelayanan.

Hasil Berdasarkan empati diartikan di Delta Spa \& Health Club Palembang memberikan perhatian yang baik terhadap pelanggan atau konsumen. Delta Spa \& Health Club Palembang menerima segala kritik dan saran dari pelanggan dan konsumen, saran yang membangun akan dijadikan sebagai perbaikan untuk kemajuan di Delta Spa \& Health Club Palembang.

\section{PENUTUP}

Berdasarkan hasil penelitian dan pembahasan yang telah dikemukakan pada bab sebelumnya, dapat ditarik kesimpulan yaitu berdasarkan hasil penelitian diketahui analisis kualitas pelayanan terhadap kepuasan konsumen di Delta Spa \& Health Club Palembang sebagian besar mempunyai sikap Puas sebesar 43,08 \%, sikap tidak puas sebesar 26,15 \%, Sangat Tidak Puas 20,0 \% dan Sangat Puas 10,77 \%, dapat disimpulkan kualitas pelayanan terhadap kepuasan konsumen di Delta Spa \& Health Club Palembang adalah Puas. 
Service Quality and Customer Satisfaction

Berdasarkan kesimpulan di atas maka implikasi dalam penelitian ini adalah sebagai berikut: 1. Kualitas pelayanan berpengaruh terhadap kepuasan konsumen di Delta Spa \& Health Club Palembang, dengan demikian hal tersebut dapat digunakan oleh pengelola terhadap kepuasan konsumen di Delta Spa \& Health Club Palembang untuk meningkatkan kualitas dari faktor-faktor tersebut. 2. Menjadi catatan bagi pengelola Delta Spa \& Health Club Palembang mengenai data kualitas layanan di Delta Spa \& Health Club Palembang.

Meskipun penelitian ini telah diusahakan sebaik-baiknya, namun tidak lepas dari keterbatasan dan kelemahan yang ada, diantaranya adalah: 1. Terbatasnya variabel yang diteliti yaitu hanya pada kualitas pelayanan terhadap kepuasan konsumen di Delta Spa \& Health Club Palembang. 2. Terbatasnya waktu, peneliti tidak mengontrol kondisi fisik dan psikis terlebih dahulu apakah responden dalam keadaan fisik yang baik atau tidak saat mengisi angket.

\section{DAFTAR PUSTAKA}

[1] Atep Adya Barata. (2003). Dasar-dasar Pelayanan Prima. Jakarta: PT Gramedika Pustaka.

[2] J. Paul Peter dan Jerry C. Olson. (1996). Perilaku konsumen dan strategi pemasaran. (Damos Sihombing. Dan Yati Sumiharti. Terjemahan).Jakarta: Erlangga.

[3] Fandy Tjiptono. (2005). Prinsip-Prinsip Total Quality Service.Edisi V. Yogyakarta. Penerbit ANDI.

[4] Toni Wijaya.(2011). Manajemen Kualitas Jasa. Jakarta. PT INdeks.

[5] Nurhasyimad. (2010). Bab 2 Tijauan Pustaka 2.1 Pengertian Pelayanan. http:// www.damandiri.or.id /file/nurhasyimadunairbab2.pdf.(diakses tanggal 30 desember 2001 jam 14.20).

[6] M. Nur Nasution. (2004). Manajemen Jasa Terpadu. Bogor: Ghalia Indonesia.

[7] Kotler, Philip \& Keller, K.L (2009) Manajemen Pemasaran. Edisi 13. Jilid 2. (Bob sabran. Terjemahan). Jakarta: Erlangga.

[8] J.supranto.(2001). Pengukuran Tingkat Kepuasan Pelanggan Untuk Menaikkan Pasar.Cet.2. Jakarta:P T Rineka Cipta.

[9] Ali Maksum. (2012). Metodologi penelitian dalam olahraga. Surabaya: Unesa University Press.

[10] Gaspersz, Vincent. (2002). Manajemen Kualitas dalam Industri Jasa. Jakarta: Gramedia.

[11] Sugiyono. (2011). Metode Penelitian Administrasi dilengkapi dengan Metode R\&D. Bandung: Alfabeta.

[12] Basu Swasta. (1993). Pengantar Bisnis Modern. Cetakan ketiga. Liberty: Yogyakarta.

[13] Parasuraman A Valerie. (2001). Delivering Quality Service. (diterjemahkan oleh sutanto). New York. The free press.

[14] Stemvelt Robert C. (2004). Reception Of Servis Quality. (di terjemahkan olehPurwoko). Allyn and bacon. Massachusetts.

[15] Yong C.Z, Yun y.w Loh L. (2003). The Quest Of Global Quality. (diterjemahkan oleh Sutanto). Jakarta: Pustaka Delapratasa.

[16] Zuhdi, S., Daud, A., Hanif, R., Nguyen, P.T. and Shankar, K., 2019. Role of Social Media Marketing in the Successful Implementation of Business Management. International Journal of Recent Technology and Engineering, 8.

[17] Zuhdi, S., Rainanto, B.H. and Apriyani, D., 2020, May. Analysis of Co-Branding Strategy to Improve Company's Competitive Power (Case Study on Walls Selection Oreo). In 2nd International Seminar on Business, Economics, Social Science and Technology (ISBEST 2019) (pp. 146-149). Atlantis Press.

[18] Zulian Yamit.(2010). Manajemen Kualitas Produk \& Jasa. Cet. 5. Yogyakarta: Ekonisia. 